\title{
STATUS HISTORICKÉHO ROMÁNU V DIELE ČARODEJNICA Z FLORENCIE OD SALMANA RUSHDIEHO
}

\section{Status of the Historical Novel in The Enchantress of Florence by Salman Rushdie}

Keywords: historical novel, romance, postmodernism

Contact: Univerzita Pavla Jozefa Šafárika v Košiciach; onuskova.gabriela@gmail.com

Salman Rushdie je britský spisovatel' indického pôvodu. Prepojenie európskej a indickej kultúry je neodmyslitel'nou súčast'ou jeho tvorby. Podobne je tomu aj v knihe Čarodejnica z Florencie, ktorá vyšla v roku 2008. Román opisuje Florenciu a indické mesto Síkrí v 16. storočí. Ústrednou postavou Čarodejnice z Florencie je Mogor dell'Amore (Mogul lásky), ktorý prepája krajiny, resp. mestá na dvoch svetadieloch v období renesancie. Na pozadí celého príbehu sú sny a predstavy o najkrajšej, najdokonalejšej žene na svete, ktorú chcú všetci muži milovat', hoci je nepolapitel'ná $\mathrm{v}$ čase a priestore.

Americký literárny kritik, Michael Dirda označil Čarodejnicu z Florencie za text, ktorý prezentuje romantiku krásy a moci $\mathrm{v}$ Taliansku a Indii. Je to podla neho romantický príbeh, v ktorom sa prelína nádhera a sila vládnutia. Dirda píše, že je to prekrásna romanca predstavujúca renesančnú mágiu a úžas (Dirda 2008: online). Polemizujeme však s týmto tvrdením, lebo nepovažujeme Rushdieho knihu za úplne totožnú s romancou, skôr sa prikláňame k názoru, že Čarodejnica z Florencie je historický román. A hoci jeden z ústredných motívov - opis a hl'adanie vel'kej lásky - priam vábi čitatel'a, považovat' knihu za historickú romancu, my v prípade tohto diela dávame prednost' označeniu historický román.

Historický text môžeme definovat' ako akýkol’vek útvar, ktorý má charakter celku a prináša informácie o historickej skutočnosti takým spôsobom a v takom rozsahu, že ponúka priestor na interpretáciu (Beneš 1995: 83). Postavy v historickom románe musia mat' špecifickú historickú črtu: „odvodenie zvláštnosti konajúcich postáv z historickej osobitosti ich čias“ (Lukács 1957: 23). Pri postavách Akbara Vel'kého či Niccolu il Machia pozorujeme aj prvky fikcie, ale zároveň je tam výrazná spätost's ich reálnymi ,,predlohami“. 
Ladislav Nagy uvádza $\mathrm{v}$ knihe Od romance $k$ románu niekol'ko názorov teoretikov na historický román: Avron Fleishman považuje historický román za román, ktorý je pevne zakotvený vo svojej prítomnosti, z ktorej smeruje k nejakej minulosti, k jej historicite a zároveň odkazuje na historicitu samotnú. Historický román podl’a Fleishmana potrebuje mat' historický rozmer, v ktorom je aktívna prítomnost' konceptu dejín ako utvárajúcej sily. David Carr poukazuje na to, že naratív historického románu vychádza z nejakého historického záznamu, podobne ako dokumenty vznikajú na základe niektorých udalostí. R. G. Collingwood si myslí, že autor historického románu zostavuje koherentný obraz histórie, tak, aby ju čitatel'ovi lepšie priblížil a začala mu dávat' zmysel. W. B. Gallie tvrdí, že historickému románu môžeme porozumiet' prostredníctvom jeho naratívnej povahy s nazeraním na rušenie rozdielu medzi sujetom a fabulou, kronikou a príbehom (Nagy 2019: 68-77).

Z predchádzajúcich definícii vyplýva, že Čarodejnica z Florencie inklinuje k historickým románom. Pomocou textu spoznávame spoločenské pomery a kultúru renesancie v Indii a vo Florencii. Dielo odkazuje na historické osobnosti, udalosti, či miesta a to, že Rushdie skutočne čerpal z historických poznatkov, dokazuje aj súpis bibliografie, ktorý uvádza v závere knihy. Mogor dell 'Amore sa spätne vracia do minulosti, aby opísal život svojich predkov a zároveň presvedčil Akbara, že je jeho strýko. Hoci Mogul lásky rozpráva príbeh na dvore cisára pár dní, rozpráva mu udalosti, ktoré sa odohrávali desiatky rokov. V diele môžeme rozdelit' čas na čas rozprávaný a čas rozprávania. Mogor dell'Amore sprítomňuje udalosti, ktoré jeho poslucháč (Akbar) dovtedy nevnímal. „Rozlišuje sa tu fakt „rozprávania“ a „rozprávaná“ vec. Ide teda o fenomenologické rozlíšenie, ktoré spôsobuje, že každé (vy)rozprávanie je aktom (vy)rozprávania čoho, ktorý nie je rozprávaním“ (Ricoeur 2004: 118).

Mogor dell'Amore prichádza na dvor cisára Akbara Vel'kého, aby mu vyrozprával svoj životný príbeh, $\mathrm{v}$ ktorom panovníkovi odhal'uje tajomstvo o mughalskej princeznej - Kara Köz (Čiernooká) a zároveň sa mu priznáva, že je jeho strýko. Prostredníctvom Mogora dell’Amore spoznávame renesančnú Florenciu, do ktorej Rushdie zahrnul významné osobnosti tej doby. V tomto kontexte sa zameriame na konkrétne významné postavy dejín, ktoré boli Mogorovi dell'Amore najbližšie.

Salman Rushdie sa raz vyslovil o svojej poetike nasledovne: „Můj př́íběh, má fiktívní země existuje - stejně jako já sám - v mírném náklonku ke skutečnosti“ (Nagy 2016: 141). V problematike rozlišovania fikcie od historických faktov, vychádzame z teórií Lubomíra Doležela. V Heterocosmice tvrdí, že fikčné jednotliviny pomocou mimetickej funkcie môžu zobrazovat' skutočnú jednotlivinu alebo skutočnú všeobecninu (Doležel 2003: 22). V našom prípade fikčnú jednotlivinu, ktorá predstavuje skutočné osobnosti, v diele zastupujú napríklad postavy, ako sú Niccoló il Machia, 
Agostino Vespucci, Andrea Doria, Lorenzo de Medici či Akbar Vel'ký. Sú to fikčné subjekty, ktorým dokážeme nájst' v skutočnom svete reálne náprotivky. Vymenované postavy sa pohybujú $\mathrm{v}$ rovnakom priestore a majú rovnaké mená ako ich reálne „,predlohy“, ku ktorým referujú v literárnom diele.

Niccoló il Machia predstavuje renesančného filozofa Niccola Macchiavelliho. Rushdie podčiarkuje ich spojitost' nielen rovnakým prostredím a podobným životným štýlom, ale aj tým, že literárna postava často vyslovuje známy výrok filozofa: „Účel svätí prostriedky“، Agostina Vespucciho by sme mohli automaticky spojit' s moreplavcom Amerigom Vespuccim, ktorý je $\mathrm{v}$ diele jeho bratrancom. Reálny Agostino bol skutočne bratranec Ameriga a zároveň asistentom Macchiavelliho (AmesLewis 2008: online). V románe sa tiež doplaví k „novému kontinentu“ ako Amerigo Vespucci. Kým literárny Agostino je priatel'om Macchiavelliho, reálny bol jeho asistentom. Andrea Doria je náprotivkom skutočného Andreu Doria, ktorý je taktiež ako jeho „literárny odraz“ taliansky námorník a admirál, ktorý bojoval s Francúzskom (Britannica, online). Lorenzo de Medici v Čarodejnici z Florencie vládol Florencii a zomrel na syfilis rovnako ako skutočný Lorenzo de Medici. Akbara Vel'kého Rushdie opisuje ako cisára, ktorý založil Síkrí s vel’kolepými palácmi, bádal vo filozofii a náboženstvách, nariad'oval obyvatel'om kedy smeli byt' ticho alebo rozprávat', mal hárem a jednu imaginárnu manželku Džódhu, ktorú miloval zo všetkého na svete najviac. Reálny Akbar Vel'ký bol takisto ako jeho literárny náprotivok mughalským cisárom, zakladatel'om Síkrí, a zaujímal sa o filozofiu (Ballhatchet 2018: online). O Akbarovi Vel'kom je v dejinách známe aj to, že sa zaujímal aj o krest’anstvo a európsku kultúru, preto pozýval do Indie Jezuitov. Práve Jezuitský rád bol prvou európskou inštitúciou, ktorá vytvorila systematickú štúdiu o indickej kultúre a vzdelanosti (Budil 2002: 76). Ríšu mughalského panovníka opisoval aj francúzsky cestovatel' Francoise Bernier, ktorý tvrdil, že panovníci vlastnia stovky vojnových slonov a po celej krajine sa rozprestierajú vel'kolepé mramorové sídla (Budil 2002: 73).

Postava, ktorá úzko súvisí s hlavnou dejovou líniou, je Antonino Argalia, ale na rozdiel od predchádzajúcich charakterov, povedané jazykom Doleželovej Heterocosmicy, to nie je fikčná jednotlivina, ktorá má v skutočnom svete reálnu jednotlivinu, ale predstavuje reálnu všeobecninu. Takýto typ fikčného subjektu je spojený s historickými, sociologickými, politickými či kultúrnymi kategóriami (Doležel 2003: 23). Antonino Argalia sa rozhodne ujst' z krest'anskej Florencie a stane sa pravou rukou osmanského sultána. Jeho čin je zhodný s mnohými vtedajšími osobnost’ami, ktoré ušli z Florencie. V 15. storočí sa mnohí pridávali na stranu Turkov, pričom to považovali za rovnaký politický krok ako spojenie sa s európskymi krajinami. Týmto 
krokom sa zároveň začali objavovat’ aj „trhliny“ v západnom svete krest’anstva (Burckhardt 2013: 73-74).

Pri zakladaní mesta Síkrí, resp. Fatehpur Sikri, Akbar Vel'ký dohliadal na každý detail, čo spôsobilo aj ornamentálnost' architektúry (prevažne z červeného pieskovca), no i napriek exkluzivite palácov, skutočným drahokamom pre obyvatel'ov Síkrí bola voda (Tajmahal.gov.in, online). Na vzácnost' vody v meste poukazuje aj Rushdie v románe, ked’ píše: „Aj cisár sa raz-dva obráti na prach, ak nemá vodu. Skutočným vládcom je voda a my všetci sme jej otroci“ (Rushdie 2009: 16). Vzhl’ad renesančnej Indie spoznávame v románe prostredníctvom Síkrí, kde sa do popredia dostávalo bohatstvo a rozmary panovníka s vel'kolepost'ou palácov mesta. „Na svitaní vyzerali strašidelné pieskovcové paláce nového vít’azného mesta Akbara Vel'kého ako stvorené z červeného dymu. Väčšina miest začne pôsobit' dojmom večnosti takmer hned' po svojom vzniku, no Síkrí vždy vyzeralo ako fatamorgána. (...) horúčava tu zmazávala hranicu medzi rojčením a blúznením, medzi fantáziou a skutočnost'ou“ (Rushdie 2009: $35)$.

Akbar Vel'ký musel opustit' Síkrí pre nedostatočné zásoby vody, podobne ako aj „románový Akbar“ v závere knihy: „Musí opustit' Síkrí, musí odíst' z milovaného červeného mesta z tieňa a dymu, nechat' ho osamotené na mieste, ktoré náhle vyschlo, aby ostalo na večné veky symbolom pominutel'nosti a náhlych zmien, ktoré môžu postihnút' aj tých najmocnejších“" (Rushdie 2009: 334). Voda symbolizuje podvedomie a je považovaná za prvotný prúd všetkého živého. Voda všetko vytvára alebo naopak ničí (Biedermann 1992: 335-337). V Akbarovom podvedomí existovala jeho imaginárna manželka Džódha, ktorú považoval za skutočnejšiu než jeho reálne manželky. Dokonca v závere sa mu v podvedomí zjavuje aj Kara Köz a až ked' Akbar pochopí, čím všetkým si v živote prešla a kto to je naozaj, až vtedy sa mu z predstavy zhmotní, vystúpi z jeho podvedomia. Voda sa spája so ženskostou už od čias antiky, ked' tento živel odkazoval na telesnost' žien a súvisel aj s vtedajšími ženskými božstvami. V starovekom Grécku bol rozšírený názor, že ženské telo obsahuje väčší podiel vody ako telo mužov. Súvislost' medzi ženou a vodou predstavuje niečo plynúce, nestále, čosi, čo neustále uniká a zároveň niečo, čo sa formuje, modifikuje a odohráva v čase (Kalnická 2000: 39-45). Postava Kary Köz unikala mužom, času a ich vedomiu. Bola nepolapitel'ná, nikomu nepatrila, nik ju poriadne nevidel a nepoznal, hoci o nej všetci snívali a neustále sa objavovala v ich vedomí. Kara Köz o sebe samej tvrdila, že jej mysel' je nestála a stále v nej niečo plynie. V jej mysli prebiehal príbeh, ktorý Mogul lásky rozprával cisárovi, $\mathrm{v}$ jej hlave človek videl minulost' aj budúcnost'. Sama o sebe hovorila ako o „Paláci spomienok“, čo by sme mohli považovat' za Rushdieho nepriamy odkaz na jeho dielo Hárún a more príbehov. 
Historický román popisuje jednotlivé udalosti a entity prostredníctvom minulosti. Zdôrazňuje subjektivizmus historických naratívov, dodržiava historický mod, aby bol román, čo najautentickejší (Nagy 2019: 14). Dejiny v historickom románe by sme mohli vnímat' aj ako produkt palimpsestu, pričom Brooke-Roseová vymedzuje jeho pät' rozličných podôb (Brooke-Roseová 1995: 124). Prvou podobou je realistický historický román. Druhý typ predstavuje vymyslený príbeh, ktorý sa odohráva v historickom období a zasahuje doň magickost'. Tretí typ je podobný druhému, nemá však v sebe magickost', ale za to je nasýtený filozofickými, teologickými a literárnymi odkazmi. Štvrtý typ dejín v palimspestovom prevedení predstavujú romány nám bližšieho, resp. nám známejšieho obdobia alebo udalosti, so zjavnou magickost'ou, ktorá je spôsobená halucináciou. Piaty typ poukazuje na palimpsestové dejiny národa a viery, pre ktoré je magickost' takmer prirodzená, ba až nepodstatná v komparácii s absurdnost'ou l’udí, opisovaných realisticky. Posledný typ je takisto výrazne spätý s imaginatívnost'ou. Ak by sme Čarodejnicu z Florencie vnímali ako výsledok palimsestu, priradili by sme ju $\mathrm{k}$ piatemu typu, lebo Rushdie istým spôsobom modifikoval dejiny tým, že nám na výsek z historickej reality ponúkol d’alší možný pohl’ad. Napríklad v dejinách je známe, že Síkrí malo problém s vodou, čo bolo hlavnou príčinou odchodu cisára, ale Rushdie vyschnutie jazera v meste pripísal hlavne tomu, že Mogul lásky uvalil na Akbara a mesto kliatbu, lebo ho neprijali medzi seba a neuverili mu jeho príbeh.

Umberto Eco delil historický román do troch kategórií. Prvá kategória predstavuje tzv. romancu, v ktorej ani nie je podstatná história ani jej pravdivost', len sa neodohráva $\mathrm{v}$ súčasnosti, je to fabulačná konštrukcia, $\mathrm{v}$ ktorej predstavivost' dostáva vol’ný rozlet. Druhú kategóriu prezentujú dumasovské romány „kepeňa a meča“. Do reálne spoznatel'nej minulosti vloží autor postavy, podl'a ktorých tú minulost' spoznávame a o ktorých hovoria aj encyklopédie, ale pripiše im niektoré činy, ktoré sa v žiadnej odbornej literatúre nepíšu no zároveň historickým faktom neprotirečia. Do tretej kategórie patria romány, ktorých postavy nie sú známe z encyklopédií, ale ich konanie slúži na lepšie pochopenie dejín, na pochopenie toho, čo sa stalo. Udalosti aj postavy sú vymyslené, ale hovoria nám o aktivitách a o prostrediach také veci, ktoré sa nedozvieme v žiadnej inej literatúre (Eco 2004: 577-578). V prípade tohto delenia, môžeme o Čarodejnici z Florencie uvažovat' ako o historickom románe „kepeňa a meča“. To, že cisár Akbar existoval, nevylučuje fakt, že mal aj imaginárnu manželku alebo Vespucci a Machia mohli mat' pokojne priatel'ský vzt'ah, nielen pracovný.

Ďalšie dôvody, prečo je Čarodejnica z Florencie historickým románom a nie romancou, vysvetl'ujeme na ich kontrastom postavení v literatúre. Romanca je vnímaná ako nenáročné čítanie a stojí v priamom protiklade $\mathrm{k}$ historickému románu, ktorý má priniest' čitatel'ovi zážitok a ešte ho aj vzdelávat'. Historický román si na rozdiel od 
romance nárokuje aj na istý status pravdivosti, lebo reprezentuje to, čo sa stalo. Je vierohodný a čitatel' dokáže identifikovat', o aké historické postavy alebo prostredie $\mathrm{v}$ dejinách ide. Romanca je chvíl'kové čítanie a je vel'mi málo pravdepodobné, aby sme našli identické miesta a osoby v minulosti, o ktorých v nej čítame (Nagy 2019: 21). Historický román mieša fikciu so skutočnost'ou, kým romanca je celá fikčná. Reevová (podl'a Nagya) hovorí, že romanca popisuje nereálne bájne osoby a veci, kým historický román zobrazuje skutočné udalosti minulosti a zachytáva dobovú kultúru a mravy, o ktorých sa v ňom píše.

Romanca alebo idylický román podl’a Northropa Fryea vychádza zo stredovekého rytierskeho románu, v ktorom hlavný hrdina bojuje za vel'ké ideály, aby získal ruku vznešenej dámy (podl'a Macura - Jedličková 2012: 258). K znakom romance patrí aj dobrodružstvo a podl'a nás je to aj jediný aspekt, ktorý sa spája s Rushdieho Čarodejnicou z Florencie. Mogul lásky precestoval vel’a krajín a vo svojom rozprávaní opisuje, čo všetko prežila Kara Köz na cestách, ked' musela neustále unikat' pred hroziacim nebezpečenstvom. Tento atribút však nepovažujeme za dostatočný na to, aby sme jednoznačne označili Rushdieho román za romancu.

Pri vysvetl'ovaní, prečo nie je Čarodejnica z Florencie romancou, sme zohl'adnili charakter fikčných postáv a miest, ktoré sú odrazom historických osôb a oblastí a takisto aj dôležitý fakt, že historické romány majú status pravdivosti, možnosti overenia fikčných entít. Taktiež sme pri vyhodnocovaní opozície romanca - historický román brali do úvahy aj naratívnu stránku Čarodejnice z Florencie. Kým pri romanci nie sú sujet a fabula v kontraste, pri historickom románe môžu byt' (Nagy 2019: 131). Pre postmoderné romány, ako aj pre poetiku Rushdieho próz, je typické, že sujet a fabula sú $\mathrm{v}$ dielach doslova prepletené a čitatel' musí knihu čítat' vel'mi pozorne, aby sa v diele „nestratill“.

Za prelomový okamih v písaní historického románu je považované práve obdobie postmodernizmu, ked' sa tento žáner začal rehabilitovat' (Nagy 2019: 145). V Rushdieho postmoderných románoch je prítomná aj tzv. naratívna autorita. Znamená to, že do svojich príbehov vkladá samého seba. Prináša zážitky a aspekty, ktoré súvisia priamo s ním, s jeho osobou (Nagy 2016: 144). Podobne je tomu aj v Čarodejnici z Florencie, kde Salman Ruhdie opisuje indické dejiny a kultúru. Dokonca pri strete svetov západ - východ, Indiu opisuje ako lepšie miesto na život než Európu: „Na Východe muži a ženy tvrdo pracovali, (...), žili úplne normálne. No títo bájni l'udia zo západných krajín, boli, ako sa zdalo, náchylní k hystérii (...)“ (Rushdie 2009: 319). Rovnako nelichotivo rozpráva o vtedy novom objavenom území - Amerike a jej domorodých obyvatel’och, ktorých Európania nazvali Indiánmi, lebo verili, že našli cestu do Indie. „Nazvat' týchto l’udí Indiánmi bolo podla Akbarovho hlbokého 
presvedčenia pre vznešených mužov a ženy Hindustanu urážlivé“" (Rushdie 2009: 320). Postmoderné beletristické texty obsahujú komentáre a vyjadrujú často názor autora na podmienky rekonštrukcie minulosti (Doležel 2008: 112).

Z uvedených argumentov považujeme za správne označit' Čarodejnicu z Florencie za historický román nie romancu. Avšak, ak by sme chceli pristúpit' ku kompromisu v tejto problematike, mohli by sme povedat', že dielo je historickým románom, ale vzhl'adom na postmodernú tvorbu, pre ktorú je príznačná medzižánrová hybridita a flexibilita, môžeme Čarodejnica z Florencie označit’ za historický román s prvkom romance (dobrodružnost').

Postmoderné historické romány dávajú do popredia čas a priestor, aby poukázali na to, že človek už nemusí byt' stredom diania a opisujú hypotetické udalosti medzi historickými osobami a miestami. Preto sa v Čarodejnici z Florencie prelína India s Talianskom, minulý a prítomný čas, sen a skutočnost' a stretávajú sa osoby z Východu s európskou spoločnost'ou.

\section{Summary}

The article describes why The Enchantress of Florence by Salman Rushdie is a historical novel, not a romance. We defend this statement through the definitions and features of the historical novel and romance. The only thing that connects the historical novel and the romance in this novel is adventure. Based on the theoriesmentioned above, especially by Doležel and Nagy, we conclude that the work is a historical novel and may contain elements of romance, but it is not exclusively a historical romance.

\section{Literatúra}

Rushdie, S. Čarodejnica z Florencie. Bratislava: Slovart, 2009.

Beneš, Z. Historický text a historická kultura. Praha: Karolinum, 1995.

Biedermann, H. Lexikón symbolov. Bratislava: Obzor, 1992.

Budil, I. Od prvotního jazyka k rase. Praha: Academia, 2002.

Burckhardt, J. Kultura renesance v Itálii. Praha: Rybka Publishers. 2013.

Doležel, L. Heterocosmica (Fikce a možné světy). Praha: Karolinum, 2003.

Doležel. L. Fikce a historie v obdobi postmoderny. Praha: Academie, 2008.

Eco, U. Meno ruže. Bratislava: Petit Press. 2004. 
Lukács, G. Historický román. Bratislava: Tatran, 1957.

Macura, V., Jedličková, A. Prưvodce po světové literární teorii 20. století. Brno: Host, 2012.

Nagy, L. Palimpsesty, heterotopie a krajiny. Praha: Karolinum, 2016.

Nagy, L. Od romance k románu a zase zpèt. Praha: Argo, 2019.

Ricoeur, P. Čas a literárne rozprávanie. Bratislava: Iris. 2004.

Welsch, W. Estetické myslenie. Bratislava: Archa, 1993.

Brooke-Roseová, Ch. Dejiny ako palimpsest. In: Collini, S. (ed.) Interpretácia a nadinterpretácia. Bratislava: Archa, 1995, s. 122-134.

Kalnická, Z. Obraz vody. In: Kiczková, Z. (ed.) Otázky rodovej identity vo výtvarnom umení, architektúre, filme a literatúre. Bratislava: Univerzita Komenského, 2000, s. 38-54.

\section{Elektronické zdroje}

Ames-Lewis, F. Agostino Vespucci's Marginal Note about Leonardo da Vinci in Heidelberg. Leonardo da Vinci Society Newsletter. 2008. Dostupné z: https://www.academia.edu/384690/Agostino_Vespucci_s_Marginal_Note_abou t_Leonardo_da_Vinci_in_Heidelberg (2021-02-22).

Andrea Doria. Encyclopedia Britannica. Dostupné z: https://www.britannica.com/ biography/Andrea-Doria-Genoese-statesman (2021-02-22).

Ballhatchet, K. Akbar. Encyclopedia Britannica. 2018. Dostupné z: https://www.britannica.com/biography/Akbar (2021-02-22).

Dirda, M. A romance of beauty and power from Italy to India. The Washington Post. 2008. Dostupné z: https://www.washingtonpost.com/wp-dyn/content/article/ 2008/05/22/AR2008052203533_pf.html (2021-02-22).

Fatehpur Sikri. Taj Mahal. Dostupné z: https://www.tajmahal.gov.in/fatehpursikri.aspx (2021-02-22). 